ISSN 1112-9867

\title{
THE RELATIONSHIP BETWEEN ORGANIZATIONAL CULTURE AND MORALISM OF PRINCIPALS IN JUNIOR SCHOOLS OF HIGH SCHOOLS
}

\author{
M. Soleimani ${ }^{1,2}$ and R. Jahanian ${ }^{2, *}$ \\ ${ }^{1}$ Department of Education, Alborz Science and Research Branch, Islamic Azad University, \\ Karaj, Iran \\ ${ }^{2}$ Department of Education, Karaj Branch, Islamic Azad University, Karaj, Iran
}

Published online: 15 May 2016

\begin{abstract}
This study aimed to investigate the relationship between organizational culture and principals' moralism in junior schools of high School, which was conducted by descriptive correlation method. The sample size of this study consisted of all principals in junior schools of high Schools in district 3 of Karaj city that according to the latest data, the number of them was 135 people. A sample size using a complete census, were determined 135 respondents. In order to measure the variables used in the study, three questionnaires of organizational culture of Fi and Denison (2003), principals moralizing of Emadifar (2009) and Karlshown et al, (2011) were used. Content validity of the questionnaire was confirmed by experts. Reliability of the questionnaire was estimated based on Cornbrash's alpha coefficient, as 0.86 and 0.88 respectively. For the analysis, descriptive and inferential statistical methods (Pearson correlation and stepwise regression) were used. The findings showed that organizational culture and all aspects of it - engaging in work, consistency, adaptability and missionprincipals' moralism of junior schools in high schools in district 3 had a significant positive correlation. The results also showed that the dimensions of involving in the work, adaptability and had ability to moralizing mission prediction of principals.
\end{abstract}

Author Correspondence, e-mail: ramezan.jahanian@kiau.ac.ir

doi: http://dx.doi.org/10.4314/jfas.v8i3s.181 
Keywords: organizational culture, ethical leadership, principals' moral behavior

\section{INTRODUCTION}

In the current situation not conform to some ethical standards, have created many concerns in the public and private sectors. Falling standards of behavior in the public sector, prompted researchers to search theory in this regard to provide appropriate executive course (Tavalaee, 2009). The more the leaders support boldly material and spiritual moral, codes of ethics and standards of professional behavior and occupation more determinant, disclosure control systems more most concentrated, more training ethical is given, legal systems, wage and incentive to be more efficient, more active civil society and non-governmental of the economic system; ethics in the public service sector will be better (Soleimani et al, 2012). Of the educational periods, high school, due to the characteristics of students' physical and mental development is more important. So, creating moral and calm environment could be better in growth and modeling them for entry into the adult world and is more effective (Tabasi, 2011). Of the most of important tools to achieve progress and advancement, are organizations that could do their duties with effiency (Nargesian, 2007). The entrance concepts such as morality, truth, belief in God or a higher power, meaning at work, altruism, etc. to research and management practices, and business, all indicate the emergence of new paradigms (Ziaee et al, 2008). The theory of moral leadership as the spring board for a new paradigm of theory, research and practice leadership has been provided. Leadership is the most important factor in the survival and continued success of the organization and has crucial role in growth, development and progress of organizations. Emphasis on the topic of management and leadership of an organization and finding success in carrying out its duties and responsibilities involve having three potentials including knowledge, skills, and moral responsibility. Leadership and management in educational organizations, particularly educational organizations not seem to settle down with general and specialized knowledge and human skills, perceptual and technical and practical experience. Practice management is one issue where there is a moral dimension to do anything (Lordship et al, 2010). In general it can be said that many of the behaviors and decisions of employees and managers in today's organizations, are under the influence of their moral values. Since the labor force, either individually or in groups and interact with others, is as the most important factor of competitive advantage, judgment of right or wrong about things on the quantity and quality of their performance and consequently, organizational performance and therefore strongly influence its success. So paying attention to the ethics of organizations is inevitable. 
Professional ethics can lead to better regulate relations, reduce differences and increase atmosphere of understanding and cooperation as well as reduce the costs of control, and affect the performance. The administrators need to take steps to improve ethical issues of the organizations (Mokhtaripoor and Siadat, 2009). Therefore, managers must provide the necessary conditions to improve moralism. In this context, the culture of an organization is of the factors that affect it (Moadab Nia, 2013). Many successful organizations in the world claim that this success have been gained through strengthening the organizational culture (Ahmadi et al, 2010). Satisfaction in these organizations are more and quitting the job are less. Stuffs are very fond of their job and doing it efficiently (Moshabaki, 2010). Considering the importance of moral values and educational organizations as well as the effect of organizational culture, this study investigated whether the organizational culture and ethical attitudes of secondary school principals of junior period there had significant correlation in District 3 of Karaj city. So far, various definitions of organizational culture have been introduced. In fact, the definition of organizational culture in the specified format generally is impossible. Organizational culture is unidentified internal infrastructure structure of a organization that appears based on the targets, technology, structure, policies, practices and products of the organization and its most visible can be seen in the behavior of staff (Askarian, 1388). Some scientists and scholars have insisted on the value of organizational culture (Robbins, 2004). Organizational culture refers to a set of values including beliefs, perceptions, and perceptions and ways of thinking or thinking that their members have in common (Dargahi et al, 2010; Morshedi, 2013; Fakhimi, 2000). In this study, to understand the culture of organization the model of Denison organizational culture (2000) that was newer and more complete was used. Denison knows organizational culture consists of four main features that each feature is divided into a number of factors, which include:

1. To engage in work (participation) which contains the employees (empowerment), teamwork the (teaming) and extending the capabilities of employees?

2. To be compatible (integration) which contains core values, employees and co-ordination and integration agreements

3. Adaptability: including change, customer orientation and organizational learning.

4. Mission: includes the strategic leadership (strategic orientation), aims, objectives and vision (vision) (Denison, 2000).

The concept of morality in general and in the specific sense in business, is infrastructure of creation and maintenance of a moral order in society and in organizations (Conaock and Johns, 1998). Ethics is one of the important aspects of an organization's culture and goes in a 
direction that is part of the strategy of an organization. Business ethics makes basic infrastructure for buisiness and improve working conditions. Similarly, quality management, also is based on morality and lead to theoretical and practical business (Zaire and Peters, 2002; Salehnia, 2012; Golparvar et al, 2012; Brown et al, 2005; Oei et al, 2010; Avatefi monfared et al, 2012). Abbas Zadeh and Boodaghi (2014) in a study entitled "the impact of ethical leadership on organizational adaptability capacity (case study: employees of Tabriz University)" achieved the results that the effects of role clarity, the benefit of the people, moral guidance, moral structures on the dependent variable (capacity of the organization accordance) were significant and could have mentioned variables, and explained 63 percent of variance of dependent variable. Karamad (2014) in a study entitled "The relationship between principals ethics and organizational culture in secondary schools in District 8 of Education and training ministry in Tehran" achieved that there was a significant positive correlation between these two variables; in other words the more the moralism in principals the higher organizational culture. Moadabnia (2013) in a study entitled "Analysis of organizational culture and its relationship with the professional ethics of teachers' showed that organizational culture and professional ethics in studied schools was higher than average and in study of demographic variables (gender, work experience, education) professional ethics in organizational culture was greater between females than man. But the professional ethics and organizational culture were similar in other demographic variables. It was concluded that by increasing the organizational culture, professional ethics and its components like professional competence of teachers, pedagogical competence, growth and development of students, evaluation of students and the right to confidentiality also increased. Salehnia (2012) in a study on "the impact of ethical leadership on ethical climate" achieved these results that ethical leadership had strong significant effect on ethical issues. Vahhabi (2012) in a study entitled "Study of ethical leadership status among high school principals Education in Sanandaj" found that teachers believe that administrators in the school environment considere more components of the moral atmosphere and ethical principles and it is rational and clear but consider the other two dimensions less. Results confirmed four confirmatory factors including moral principles, moral atmosphere, moral and ethical behavior. Karaminia et al (2010) in a study on "The relationship between leadership style and organizational culture and commitment" achieved these results that the leadership styles used by the commanders of the staff leadership style was interactive or exchange. Organizational culture was the dominant intellectual culture. The highest mean score of organizational commitment was given to normative commitment. There was a positive significant relationship between transformational leadership style and 
organizational culture exchange and commitment. Connor (2006) in a study entitled "evaluation of Organizational Ethics; differs or gaps" concluded that the management has made mistake and there is big gap between concept and reality. Clark (2009) in a study entitled "Moral intelligence in schools" concluded that moral intelligence by the meaning of human ability refers to apply moral principles to advance personal goals, values and activities. Moral intelligence is based on four competencies related to integrity, responsibility, forgiveness and compassion. School principals and teachers will benefit from moral intelligence and can create these competencies in students, support and respect. High moral intelligence in schools and in the community form more effective organizations, and students will be trained better, be smart and successful and accepted human rights principles and value. Aydogdu and Asikgil (2011) in a study entitled "The impact of transformational leadership behaviors on organizational culture: Application in the pharmaceutical industry" concluded that there was a significant positive correlation between transformational leadership and organizational culture. Binzohari et al, (2012) in a study entitled "The impact of organizational culture on the relationship between transformational leadership and job satisfaction" concluded that there was a significant positive correlation between transformational leadership style with organizational culture and job satisfaction. Sunar and Tabancali in a study investigated the ethical behavior in their school principals and surveyed 389 principals, of which 234 and 155 were elementary and secondary school principals, respectively. Their ethical behavior investigated in six tolerance, justice, responsibility, honesty, democracy and respect and concluded that principals' ethical behavior was at moderate and high-level.

\section{CONCEPTUAL MODEL AND RESEARCH HYPOTHESES}

Conceptual Model of variables, dimensions, and their relationship indicate a coherent manner and forms the basis of the research work. The aim of this study was to investigate the relationship between organizational culture and ethical attitudes of secondary school principals of first period in district 3 in Karaj city that is given in Figure (1). In this study to evaluate the variables, the model of Denison (1998) was used to examine the organizational culture. According to this model, organizational culture, includes four dimensions of mission, engaging in work, the adaptation and Compatibility. Also to evaluate principals' moralism the Emadifar model (2009) and Karlshown et al (2011) were used. Accordingly principals moralism dimensions include (integrity, regulate activity within the framework of moral, confidence, efforts to promote employees, to express dissent, fairness, ethical guidelines, individual orientation, power sharing, role clarity (Fig. 1). 


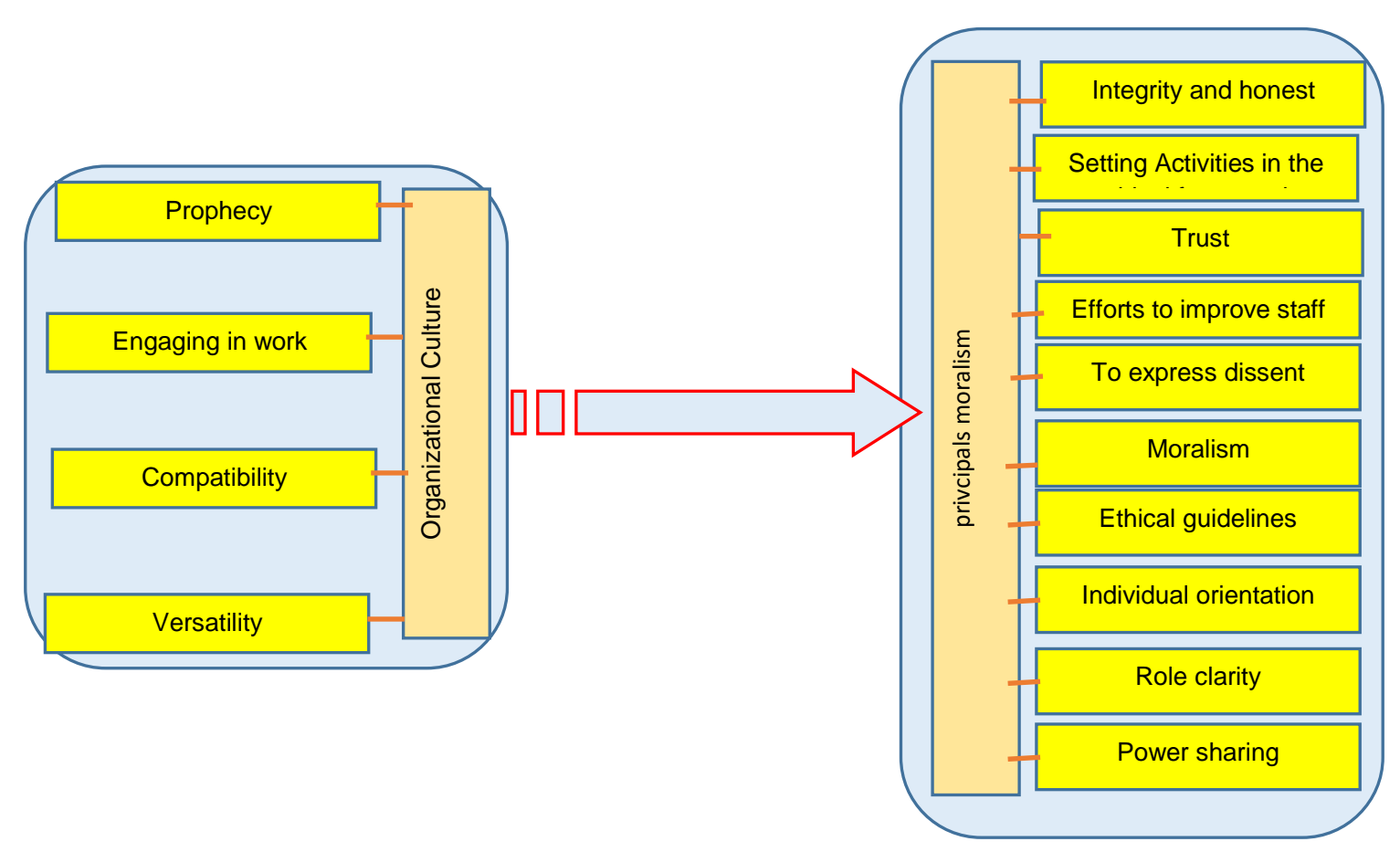

Fig.1. Conceptual Model Research

\section{RESEARCH HYPOTHESIS}

According to the survey and theoretical research as well as in the shown conceptual model, this study dealed with the following assumptions:

1. There is a correlation between organizational culture and principals' moralism in first period of secondary school principals in district 3 of Karaj city.

2. There is a correlation between organizational culture in "engaging in business" dimension and principals moralism in first period of secondary school in district 3 of Karaj city.

3. There is a correlation between organizational culture in "compatibility" dimension and principals moralism in first period of secondary school in district 3 of Karaj city.

4. There is correlation between organizational culture in the "adaptability" and moralism dimensions of school principals in first period of, moderate level in district 3 in Karaj city.

5. There is a correlation between organizational culture in the "mission" dimension and principals moralism in first period of moderate level in district 3 of Karaj city.

\section{The sample size, sample and sampling}

The sample size of the research were all of the principals of first period of moderate level in district 3 of Karaj city, that according to the latest data and statistics the number of principles were 135 people. Due to the small number of sample size $(n=135)$, complete census method was used. 


\section{Research Tools}

\section{A) Moralism of principals}

The first tool used in this study was principals' moralism questionnaire. This questionnaire was made of combination of Emadifar (2009) and Karlshown et al (2011) that 41 items were on the questionnaire of Emadi (2009). The dimension of honesty and integrity, activities regularity within the framework of moral, confidence, efforts to promote employees, to express opposition opinions, the questionnaire of Emadi (2009) was used. The reliability and validity of this scale has been taken by the Emadi Far (2009) and the Cronbach's alpha coefficient in this research was 0.86._Following the implementation of the questionnaire was given. The dimensions of fairness, ethical guidelines, individual orientation, power sharing, and transparency were determined using Karlshown et al questionnaire (Table 1).

Table 1. Matching moralism questionnaire of principals with its components

\begin{tabular}{|c|c|}
\hline Questions & components \\
\hline $2-4-6-10-16-17-21-23-35-36-40$ & Integrity and honesty \\
\hline $1-9-12-18-24-25-32-38-41-$ & $\begin{array}{c}\text { Setting Activities in the ethical } \\
\text { framework }\end{array}$ \\
\hline $7-8-13-14-19-20-28-29$ & Trust \\
\hline $3-15-22-26-31-37-39$ & Efforts in improving staff \\
\hline $5-11-24-27-30-33$ & To express dissent \\
\hline 42 to 46 & Fair \\
\hline 47 to 50 & Individual orientation \\
\hline 51 to 54 & Ethical guidelines \\
\hline $55-60$ & Share power \\
\hline $61-65$ & role transparency \\
\hline
\end{tabular}

B) Organizational Culture: The second tool used in this study, was organizational culture questionnaire that was designed by Fay and Denison (2003). This questionnaire had four components including mission, consistency, adaptability and work involving. The questionnaire consisted of 36 items, and was scored based on Likert scale five choices (strongly disagree (-1) to strongly agree (-5)). Reliability coefficients of each of the components of organizational culture questionnaire (engaging in work, consistency, adaptability, responsibility) in research of Morshedi (2012), were calculated 0.84, 0.82, 0.80 
and 0.80 , respectively that showed the high accuracy of measuring instruments used in this study (Table 2).

Table 2. Implementation of organizational culture questionnaire with its components

\begin{tabular}{|c|c|}
\hline Questions & components \\
\hline $1-9$ & Engaging in work \\
\hline $10-18$ & Adaptability \\
\hline $19-27$ & Compatibility \\
\hline $28-36$ & Mission \\
\hline
\end{tabular}

\section{Data Analysis Methods}

Analysis of data of this study were conducted by the statistical software SPSS at two levels of descriptive and inferential. In the descriptive statistics, statistical characteristics such as frequency, percentage, mean and standard deviation and in inferential statistics and the Pearson correlation was used.

\section{RESEARCH FINDINGS}

In this section, based on the information provided, analysis of the raised hypotheses would be discussed.

Hypothesis (1): there was a correlation between organizational culture and schools principals' morality in first period of moderate level in district 3 of Karaj. To examine the correlation between organizational culture and schools principals morality in first period of moderate level in district 3, the Pearson correlation was used which results in are presented in Table 3.

Table 3. The correlation between organizational culture and principals' morality

\begin{tabular}{|c|cccc|c|}
\hline $\begin{array}{c}\text { significance } \\
\text { level }\end{array}$ & $\begin{array}{c}\text { Correlation } \\
\text { direction }\end{array}$ & $\begin{array}{c}\mathbf{R} \\
\text { squared } \\
(\mathrm{R})^{2}\end{array}$ & correlation & $\begin{array}{c}\text { dependent } \\
\text { variable }\end{array}$ & $\begin{array}{c}\text { independent } \\
\text { variable }\end{array}$ \\
\hline 0.000 & positive & 0.43 & 0.669 & principals' & organizational \\
& & & morality & culture \\
\hline
\end{tabular}

As can be seen from the above table, there was a significant positive correlation organizational culture and principal's morality in schools in first period of moderate level in district 3. This relationship is significant at alpha level of 0.01 . In the other words, the more 
the schools have organizational culture, the more effective the moralism of principals in the first period of secondary level of district 3; the coefficient of determination calculated showed that organizational culture, explained $43 \%$ of the variance of moralism of principals.

Hypothesis (2): there was correlation between organizational culture in "engaging in business" dimension and school principals moralism in first period of secondary level in district 3 of Karaj. To examine the correlation between organizational culture in terms of engaging in work and moralism of principals in the the first period of secondary school in the district 3 of Karaj city the Pearson correlation was used. The results are provided in Table 4.

Table 4. The correlation between engagement in work and principals moralism

\begin{tabular}{|c|cccc|c|}
\hline $\begin{array}{c}\text { significance } \\
\text { level }\end{array}$ & $\begin{array}{c}\text { Correlation } \\
\text { direction }\end{array}$ & $\begin{array}{c}\mathbf{R} \\
\text { squared } \\
\mathbf{T}(\mathbf{R})^{\mathbf{2}}\end{array}$ & correlation & $\begin{array}{c}\text { dependent } \\
\text { variable }\end{array}$ & $\begin{array}{c}\text { independent } \\
\text { variable }\end{array}$ \\
\hline 0.000 & positive & 0.23 & 0.482 & principals & engagement in \\
& & & moralism & work \\
\hline
\end{tabular}

As can be seen in above table, there was a positive correlation in engaging at work and school principals' moralism in first period of moderate level in district 3 of Karaj city that was significant at alpha level of 0.01. In other words, the more the schools engage in further work, the more school principals' morality in first period of secondary school would be obtained; Also calculated the coefficient of determination indicated that the variable of engaging in work, explained a $23 \%$ of the variance of principals morality.

Hypothesis (3): there is a correlation between organizational culture in "compatibility" and principals' morality in the first period of secondary school in district 3.

To examine the relationship between organizational culture in adaptability and moralism dimension in school principals in first period of secondary level in district 3, the Pearson correlation was used which results are provided in Table 5.

Table 5. Correlation between consistency and principals' morality

\begin{tabular}{|c|cccc|c|}
\hline $\begin{array}{c}\text { significance } \\
\text { level }\end{array}$ & $\begin{array}{c}\text { Correlation } \\
\text { direction }\end{array}$ & $\begin{array}{c}\text { squared } \\
\mathbf{R}\end{array}$ & correlation & $\begin{array}{c}\text { dependent } \\
\text { variable }\end{array}$ & $\begin{array}{c}\text { independent } \\
\text { variable }\end{array}$ \\
\hline 0.000 & positive & 0.14 & 0.388 & $\begin{array}{c}\text { principals } \\
\text { morality }\end{array}$ & Compatibility \\
\hline
\end{tabular}


As can be seen from the above table, there was a significant positive correlation between compatibility and school principals' morality in the first period of moderate level in district 3 of Karaj city. This correlation was significant at alpha level of 0.01. In other words, the more the schools compatibility, the more school principals' morality in first period of secondary school would be obtained; also calculated the coefficient of determination indicated that the variable of compatibility, explained a $14 \%$ of the variance of principals morality.

Hypothesis (4): there is correlation between organizational culture in dimension of "adaptability" and school principals' moralism in the first period of moderate level in district 3 of Karaj city

To examine the correlation between organizational culture in adaptability and moralism dimension in school principals in first period of secondary level in district 3, the Pearson correlation was used which results are provided in Table 6.

Table 6. Correlations between the "adaptability" and principals' moralism

\begin{tabular}{|c|cccc|c|}
\hline $\begin{array}{c}\text { significance } \\
\text { level }\end{array}$ & $\begin{array}{c}\text { correlation } \\
\text { direction }\end{array}$ & $\begin{array}{c}\text { squared } \\
\mathrm{R}\end{array}$ & correlation & $\begin{array}{c}\text { dependent } \\
\text { variable }\end{array}$ & $\begin{array}{c}\text { independent } \\
\text { variable }\end{array}$ \\
\hline 0.000 & positive & 0.30 & 0.55 & $\begin{array}{c}\text { principals' } \\
\text { moralism }\end{array}$ & adaptability \\
\hline
\end{tabular}

As can be seen from the above table, there was a significant positive correlation between adaptability and school principals' morality in the first period of moderate level in district 3 of Karaj city. This correlation was significant at alpha level of 0.01 . In other words, the more the schools adaptability, the more school principals' morality in first period of secondary school would be obtained; also calculated the coefficient of determination indicated that the variable of compatibility, explained a $30 \%$ of the variance of principals morality.

Hypothesis (5): there is correlation between organizational culture in dimension of "mission" and school principals' moralism in the first period of moderate level in district 3 of Karaj city. To examine the correlation between organizational culture in mission and moralism dimension in school principals in first period of secondary level in district 3, the Pearson correlation was used which results are provided in Table 7. 
Table 7. The correlation between mission and principals moralism

\begin{tabular}{|c|c|c|c|c|c|}
\hline $\begin{array}{c}\text { significance } \\
\text { level }\end{array}$ & $\begin{array}{c}\text { correlation } \\
\text { direction }\end{array}$ & $\begin{array}{c}\text { squared } \\
\text { R } \\
(\mathrm{R})^{2}\end{array}$ & correlation & $\begin{array}{c}\text { dependent } \\
\text { variable }\end{array}$ & $\begin{array}{c}\text { independent } \\
\text { variable }\end{array}$ \\
\hline 0.000 & positive & 0.39 & 0.639 & $\begin{array}{c}\text { principals' } \\
\text { moralism }\end{array}$ & mission \\
\hline
\end{tabular}

As can be seen from the above table, there was a significant positive correlation between mission and school principals' morality in the first period of moderate level in district 3 of Karaj city. This correlation was significant at alpha level of 0.01 . In other words, the more the schools mission, the more school principals' morality in first period of secondary school would be obtained; also calculated the coefficient of determination indicated that the variable of mission, explained a $39 \%$ of the variance of principals morality.

\section{SUGGESTIONS}

In this section based on the results of data collection and statistical analysis of the role of organizational culture, proposals will be offered.

- Due to factors related to compliance with moralizing, it is suggested to principals strengthen components of their action. For this purpose have to find ways to meet the needs of change and to understand organizations environment, respond to current stimuli and forward of upcoming changes. Understand and respond to the demands of the workers and strives to meet future demands. Organization principals should also receive environmental signals, translate and interpreted them and prepare opportunities to encourage creativity, style, knowledge and abilities of the staff.

- With regard to the relationship between principals involved in working with moralizing, it is suggested that through consultation with staff and sharing in decision-making, could reflect employee concerns, and earn new ideas and grow creativity and integrity among employees. More attention of principals in communication with teachers and administrators in public meetings within each domain, in order to create a suitable space for the opinions and information seeking the cooperation and needed support when need it in case of problems in the unit.

- The most important issue of strategic vision is preparing mission statement and each organization's mission. 
1. organizations must form teams to work and thorough examination of the organizational environment identify opportunities and threats and take necessary measures in a timely manner.

2. Each year the senior principals of each organizations review their strategies.

3. In-service training courses for employees and principals to be held in this regard to earn more awareness of employees and principals with the concept of strategic perspective.

\section{REFERENCES}

[1] Tollayi Roohollah. 2009. Factors affecting the ethical behavior of employees in the organization. Journal of human development and extension of police, 6 (25): 43-48.

[2] Dargahi Hossein, Eskandari Mahnaz, Shaham Golsa. 2010. Comparison between existing and desired organizational culture from the perspective of executives at Tehran University of Medical Sciences. Faculty of Allied Health Sciences, Tehran University of Medical Sciences Hournal (Payavard health). Volume 4. Number 1 and 2.

[3] Robbins Estephan P. 2007. Principles of Organizational Behavior. Translated by Ali Parsaeian. Tehran: Amir Kabir.

[4] Soleimani Nader, Abbaszadeh Naser, Niaz Azeri Behrooz. 2012. The relationship between job satisfaction and job stress on work ethics and professional technical training organization in Tehran. Journal of Research New Approaches in Educational Administration. 3 (1-9): 21-36.

[5] Siadat Seyed Ali, Nasr-Esfahani Ali, Allahyari Somayeh. 2010. Ethical leadership in educational organizations, Cultural engineering Quarterly, 46: 38. 46.

[6] Sadeghi Ali Mansour, Hassan Zadeh Ali, Bagheri Qodrat Allah, Amiri Ali Naqi. 2012. Internal and external factors affecting customer satisfaction in the financial institution and credit Salehin (next Bank), Bank Services Marketing Conference, Tehran, IRIB International Conference Center.

[7] Salehinia Manijeh. 2012. The effect of moral leadership on ethical climate, Journal of Ethics in Science and Technology, 7 (2 (20)): 86. 96.

[8] Ziaee Mohammad Sadegh, Nargesian Abbas, Abiaghy Isfahani Saeed. 2008. Spiritual leadership role in empowering employees of Tehran University, Public Administration, Volume 1, Number 1, 67- 86.

[9] Tabasi Seyedeh Zakiyeh. 2011. The relationship between professional ethics and their efficiency in high schools in Mashhad, thesis Department of Education, Faculty of Education and Psychology, University of Al Zahra. 
[10]Abbas Zadeh Mohammad, Bodaghi Ali. 2014. On the impact of ethical leadership capacity organizational adaptability (the case of employees of Tabriz University), Public Administration Quarterly, 6 (18): 289-308.

[11] Askarian Mohammad. 2009. The concept of organizational culture, human development of police bimonthly, 6 (24): 101-124.

[12] Avatefi Monfared Ehsan, Mahdad Ali, Mir Jafari Sayyed Ahmed. 2012. The relationship between ethical leadership and workplace mental health and organizational trust, Journal of Ethics in Science and Technology 7 (3): 44-51.

[13] Karamad Jalal. 2014. The relationship between ethics and organizational culture oriented managers in secondary schools in District 8 of Education minstry of Tehran, Master's thesis, Faculty of Social Sciences, Islamic Azad University, Central Tehran Branch.

[14] Karaminia R, Salimi Hossain, Amini Ali. 2010. The relationship between leadership style and organizational culture and commitment, Journal of Military Medicine, 12 (2 (44)): 65-70.

[15] Golparvar M, Javadian Zahra, Hossainzadeh Khairallah. 2011. Structural model of psychological contract, organizational justice, ethical leadership and organizational support leader-member exchange, The new in industrial and organizational psychology, 7: $32-21$.

[16] Mokhtaripoor Marzieh, Siadat Ali. 2009. Management moral intelligence. Monthly plan, the $16^{\text {th }}$, No. 205.

[17] Orshedi Z. 2013. The relationship between the perception of transformational leadership and organizational culture and organizational innovation in Qom Islamic Azad University, Master's Thesis, School of Management, University of Isfahan.

[18] Moshabaki Asghar. 2010. Management of Organizational Behavior: functional analysis, the value of human behavior. Tehran: Publication of Termeh, Second Edition.

[19] Moadab nia Motahareh. 2013. Analysis of organizational culture and its relationship with the professional ethics of teachers, master's thesis, Faculty of Education and Psychology, University of Sistan and Baluchestan.

[20] Wahhabi Gharibeh. 2012. The study of moral leadership among high school principals education in the city of Sanandaj, the master's thesis, Faculty of Literature and Humanities, University of Kurdistan.

[21] Avey JB, Palanski ME, Walumbwa FO (2010). When Leadership Goes Unnoticed: The Moderating Role of Follower Self-Esteem on the Relationship Between Ethical Leadership and Follower Behavior. Journal of Business Ethics, 98:573-582. 
[22] Aydin I, Karaman-Kepenekci Y. (2008). Principals' opinions of organizational justice in elementary schools in Turkey. Journal of Educational Administration,46(4): 497-513.

[23]Bin Zahari, I., Shurbagi, Ali \& Mohamed, Adel (2012). The Effect of Organizational Culture and the Relationship between Transformational Leadership and Job Satisfaction in Petroleum Sector of Libya, International Business Research, 5(9): 234-245.

[24]Brown ME, Trevino LK, Harrison D (2005). Ethical leadership: A social learning perspective for construct development and testing. Organizational behavior and Human Decision Processes, 97: 134 -117.

[25]Brown, M. E. (2007); Misconceptions of Ethical Leadership: How to Avoid Potential Pitfalls, Organizational Dynamics, 36(2):140-155.

[26]Clarken, R. H. (2009). Moral Intelligence in the Schools, Paper presented at the annual meeting of the American Educational Research Association. Moral Intelligence, 1-9.

[27]Conaock, M., \& Johns, L., (1998), "Total quality management and its humanistic orientation towards organizational analysis", The TQM Magazine, 10(4): 26-31.

[28]Connor; K.T (2006) Assessing organizational ethics: measuring the gap, Industrial and commercial training; 3:198- 155.

[29]Denison, D. R. (2000). "Organizational Culture: Can it be a Key Lever for Driving Organizational Change?", In Cooper, C.L., Cartwright, S. \& Earley, P.C. (Eds.), The International Handbook of Organizational Culture and Climate (pp. 347-376), Chichester: John Wiley \& Sons.

[30]Flynn, G., (2008), the Virtuous Manager: A Vision for Leadership in Business. Journal of Business Ethics, 78: 359-372.

[31] Sunar, O.B., Tabancali, E (2012). Ethic behaviors of school's administrations, Procedia Social and Behavioral Sciences, 46: 2457 - 2461.

[32]Zairi, M., and Peters, J (2002). "The impact of social responsibility on business performance ", Managerial Auditing journal, 17(4):422-456.

\section{How to cite this article:}

Soleimani $\mathrm{M}$ and Jahanian $\mathrm{R}$. The relationship between organizational culture and moralism of principals in junior schools of high schools. J. Fundam. Appl. Sci., 2016, 8(3S), 276-289. 